\title{
Distribution of ovarian follicular populations in the dairy cow within 35 days after parturition
}

\author{
J. J. Dufour and G. L. Roy \\ Agriculture Canada Research Station, P.O. Box 90, Lennoxville, Quebec, Canada JIM IZ3
}

\begin{abstract}
Summary. Ovaries were obtained at slaughter from 12 Holstein dairy cows at 15, 25 or 35 days after their 4th calving. Non-atretic and atretic antral follicles were separated into 6 size classes according to size and the numbers in each class were expressed as a percentage of the total for each ovary. Non-atretic follicles of diameter $0 \cdot 16-0 \cdot 28 \mathrm{~mm}$ decreased from $27.5 \%$ at Day 15 to $1.5 \%$ at Day 35 whereas those of $0.29-0.67 \mathrm{~mm}$ and $0.68-1.57 \mathrm{~mm}$ diameter increased from 37.4 to $47.2 \%$ and from 11.5 to $17.3 \%$ respectively (all $P<0.05$ ). The proportions of follicles measuring 1.58-3.68, 3.69-8.56 and $>8.56 \mathrm{~mm}$ remained almost constant. The atretic follicles of $0.29-3.68 \mathrm{~mm}$ varied significantly in number according to the post-partum interval and to whether they were in the ovary containing the CL of pregnancy. It is concluded that the CL of pregnancy and/or the conceptus have a carry-over effect on the rate of growth of the antral follicles even after parturition.
\end{abstract}

\section{Introduction}

The inhibitory action of pregnancy on follicular development in the cow (Nalbandov \& Casida, 1940; Rexroad \& Casida, 1975) is maintained after calving by a mechanism postulated to involve the previously gravid uterine horn and/or the ovary bearing the corpus luteum of the pregnancy. This inhibitory action is maintained during the first 20 days post partum and reduces the frequency of ovulation from the ovary ipsilateral to the previously gravid uterine horn (Saiduddin, Riesen, Tyler \& Casida, 1967). The purpose of the present study was to determine whether this inhibitory action exerted its effect on the distribution of follicular populations in ovaries of lactating dairy cows early in the post-partum period.

\section{Materials and Methods}

Twelve purebred Holstein cows were randomly assigned after their fourth parturition to three different post-partum intervals, i.e. Day 15, Day 25 or Day 35. Ovaries were collected within $5 \mathrm{~min}$ of slaughter, perfused immediately with Bouin-Hollande's fluid through the utero-ovarian artery and kept in that solution for $72 \mathrm{~h}$ after removal. The ovaries were then embedded in paraffin wax and serially sectioned at a thickness of $10 \mu \mathrm{m}$. One out of five sections was mounted, stained with haematoxylin and observed microscopically. The ovaries were identified in relation to the corpus luteum of the previous pregnancy. All antral follicles were counted, measured and classified as nonatretic or atretic. A follicle was said to be atretic when 5 or more pycnotic bodies were counted on the edge of or amongst the granulosa cells of the section studied. All measurements were from the section where the oocyte was found except for the largest follicles for which the measurements were recorded from the largest section limited by the basement membrane.

The area of each follicle was determined by tracing with an electronic planimeter the follicle at 
the basement membrane through a drawing tube fixed at the microscope. To conform with the normal convention of expressing follicular size as a diameter, the area of the follicle expressed in $\mu \mathrm{m}^{2}$ was assumed to be circular and the diameter was then calculated and expressed in mm. Appearance of antrum formation was calculated according to the criteria described by Mariana \& N'Guyen (1973). Atretic and non-atretic antral follicles were grouped according to the following six diameter classes : $0.16-0.28 \mathrm{~mm}, 0.29-0.67 \mathrm{~mm}, 0.68-1.57 \mathrm{~mm}, 1.58-3.67 \mathrm{~mm}, 3.68-8.56 \mathrm{~mm}$ and $>8.56 \mathrm{~mm}$. The number of follicles in each class was expressed as a percentage of the total number of follicles present in each ovary. The following factors and interactions were used in the statistical model to evaluate the dynamics of follicular growth after parturition : days post partum, ovary status (i.e. with or without $\mathrm{CL}$ ), day by ovary, cow and cow by ovary. Differences amongst means were tested by Duncan's multiple range test (Steel \& Torrie, 1960).

\section{Results}

\section{Numbers of follicles}

The 2227 developing non-atretic follicles observed in the 24 ovaries were used to determine the mean diameter of the follicles when antrum formation begins. The minimum diameter was $0 \cdot 138$ $\mathrm{mm}$ in the ovary without the CL at Day 35 and the maximum was $0.166 \mathrm{~mm}$, also in the ovary without the CL but at Day 25. Since no significant difference was noted amongst stages and ovary status, the mean diameter at antrum formation was considered to be $0.156 \mathrm{~mm}$ for all growing follicles.

The mean total number of antral follicles per ovary ranged from 141.8 at Day 25 to 228.3 at Day 15 (Table 1). Although the mean total number of non-atretic follicles was not signifciantly different $(P>0.05)$ amongst the post-partum intervals, there was a tendency for the percentage of non-atretic follicles to be higher at Day $15(P<0.07)$ than at Day 25 to 35. At all three post-partum times the ovary bearing the CL contained more non-atretic follicles (overall $82.1 \%$ ) than did the contralateral ovary $(78.5 \%)(P<0.01)$.

Table 1. Mean number of antral follicles in each ovary at different post-partum intervals and according to the position of the CL of the previous pregnancy

\begin{tabular}{|c|c|c|c|c|c|c|}
\hline \multirow[b]{3}{*}{$\begin{array}{c}\text { Follicular } \\
\text { type }\end{array}$} & \multicolumn{6}{|c|}{ Days post partum } \\
\hline & \multicolumn{2}{|c|}{15} & \multicolumn{2}{|c|}{25} & \multicolumn{2}{|c|}{35} \\
\hline & $\begin{array}{l}\text { Ovary } \\
+\mathrm{CL}\end{array}$ & $\begin{array}{l}\text { Ovary } \\
\text { - CL }\end{array}$ & $\begin{array}{l}\text { Ovary } \\
+\mathrm{CL}\end{array}$ & $\begin{array}{l}\text { Ovary } \\
-\mathrm{CL}\end{array}$ & $\begin{array}{c}\text { Ovary } \\
+\mathrm{Cl}\end{array}$ & $\begin{array}{l}\text { Ovary } \\
-\mathrm{CL}\end{array}$ \\
\hline $\begin{array}{l}\text { Non-atretic } \\
(\%) \\
\text { Atretic }\end{array}$ & $\begin{array}{l}184 \cdot 0 \\
(84 \cdot 0)^{\mathrm{a}} \\
33 \cdot 3\end{array}$ & $\begin{array}{l}191 \cdot 0 \\
(83 \cdot 5)^{\mathrm{b}} \\
37 \cdot 3\end{array}$ & $\begin{array}{l}147 \cdot 3 \\
(85 \cdot 7)^{\mathrm{a}} \\
23 \cdot 8\end{array}$ & $\begin{array}{l}113 \cdot 5 \\
(78 \cdot 3)^{\mathrm{b}} \\
28 \cdot 3\end{array}$ & $\begin{array}{l}116 \cdot 0 \\
(76 \cdot 5)^{\mathrm{a}} \\
36 \cdot 3\end{array}$ & $\begin{array}{l}139 \cdot 0 \\
(73 \cdot 7)^{\mathrm{b}} \\
51 \cdot 8\end{array}$ \\
\hline
\end{tabular}

Error mean square for percentage non-atretic $=9.04 ;$ d.f. $=9$.

Treatment means with different letters $(a, b)$ are significantly different $(P<0.05)$.

\section{Distribution of follicles}

Amongst the 6 follicular size classes, most atretic and non-atretic follicles were found in Class 2 $(45.7 \%$ of all follicles), followed by those of Class 3 at $21.6 \%$, of Class 4 at $17.0 \%$ and of Class 1 at $15 \%$. Classes 5 and 6 together contained only $1.3 \%$ of all the antral follicles present in an ovary (Tables 2 and 3). 
Table 2. Mean percentages of non-atretic and atretic antral follicles in the ovary bearing the corpus luteum of pregnancy or on the contralateral ovary at,Days 15, 25 and 35 post partum according to size classes

\begin{tabular}{|c|c|c|c|c|c|c|}
\hline & \multicolumn{2}{|c|}{ Folicles } & \multirow[b]{2}{*}{ Class } & \multicolumn{3}{|c|}{ Days post partum } \\
\hline & Type & Size $(\mathrm{mm})$ & & 15 & 25 & 35 \\
\hline \multirow[t]{2}{*}{ Ovary with CL } & Antral, non-atretic & $\begin{array}{c}0.16-0.28 \\
0.29-0.67 \\
0.68-1.57 \\
1.58-3.67 \\
3.68-8.56 \\
>8.56\end{array}$ & $\begin{array}{l}1 \\
2 \\
3 \\
4 \\
5 \\
6\end{array}$ & $\begin{array}{r}30 \cdot 8 \\
35 \cdot 3 \\
10 \cdot 8 \\
6 \cdot 9 \\
0 \cdot 3 \\
0 \cdot 0\end{array}$ & $\begin{array}{r}13 \cdot 6 \\
46 \cdot 2 \\
16 \cdot 6 \\
8 \cdot 9 \\
0 \cdot 3 \\
0 \cdot 3\end{array}$ & $\begin{array}{r}0.9 \\
48 \cdot 0 \\
17 \cdot 4 \\
9 \cdot 6 \\
0.2 \\
0.4\end{array}$ \\
\hline & Antral, atretic & $\begin{array}{c}0.16-0.28 \\
0.29-0.67 \\
0.68-1.57 \\
1.58-3.67 \\
3.68-8.56 \\
>8.56\end{array}$ & $\begin{array}{l}1 \\
2 \\
3 \\
4 \\
5 \\
6\end{array}$ & $\begin{array}{l}0 \cdot 2 \\
2 \cdot 0 \\
5 \cdot 9 \\
7 \cdot 0 \\
0 \cdot 7 \\
0 \cdot 2\end{array}$ & $\begin{array}{l}0 \cdot 0 \\
0 \cdot 3 \\
6 \cdot 0 \\
7 \cdot 8 \\
0 \cdot 2 \\
0 \cdot 0\end{array}$ & $\begin{array}{l}0.6 \\
8.9 \\
5 \cdot 8 \\
7.6 \\
0.5 \\
0 \cdot 1\end{array}$ \\
\hline \multirow[t]{2}{*}{$\begin{array}{l}\text { Ovary without } \\
\text { CL }\end{array}$} & Antral, non-atretic & $\begin{array}{c}0.16-0.28 \\
0.29-0.67 \\
0.68-1.57 \\
1.58-3.67 \\
3.68-8.56 \\
>8.56\end{array}$ & $\begin{array}{l}1 \\
2 \\
3 \\
4 \\
5 \\
6\end{array}$ & $\begin{array}{r}24 \cdot 2 \\
39 \cdot 6 \\
12 \cdot 2 \\
6 \cdot 9 \\
0 \cdot 6 \\
0 \cdot 0\end{array}$ & $\begin{array}{r}15 \cdot 4 \\
38 \cdot 8 \\
14 \cdot 1 \\
9 \cdot 3 \\
0 \cdot 8 \\
0 \cdot 0\end{array}$ & $\begin{array}{r}2 \cdot 0 \\
46 \cdot 4 \\
17 \cdot 3 \\
7 \cdot 6 \\
0 \cdot 3 \\
0 \cdot 2\end{array}$ \\
\hline & Antral, atretic & $\begin{array}{c}0.16-0.28 \\
0.29-0.67 \\
0.68-1.57 \\
1.58-3.67 \\
3.68-8.56 \\
>8.56\end{array}$ & $\begin{array}{l}1 \\
2 \\
3 \\
4 \\
5 \\
6\end{array}$ & $\begin{array}{l}0.0 \\
1.7 \\
5.7 \\
8.1 \\
0.9 \\
0.0\end{array}$ & $\begin{array}{r}0 \cdot 0 \\
1.4 \\
9 \cdot 6 \\
10 \cdot 2 \\
0 \cdot 4 \\
0 \cdot 1\end{array}$ & $\begin{array}{r}0.0 \\
5.5 \\
7.5 \\
12.4 \\
0.6 \\
0.4\end{array}$ \\
\hline
\end{tabular}

The significant differences according to the analysis of variance in Table 3 are explained in the text.

\section{Non-atretic follicles}

The percentage of non-atretic follicles present in an ovary differed significantly for the various post-partum intervals studied. On Day 15 post partum, $27.5 \%$ of the follicles were of Class 1 , significantly more than at Day $25(14.5 \%)$ and Day $35(1.5 \%)(P<0.01)$. On the other hand, the numbers of follicles in Classes 2 and 3 increased significantly from 37.5 and $11.5 \%$, respectively, at Day 15 to 42.5 and $15.4 \%$ at Day 25 and reached 47.2 and $17.4 \%$ at Day $35(P<0.06)$. Days post partum and ovary status had no effect $(P>0.05)$ on the percentage of non-atretic antral follicles of Classes 4,5 and 6.

\section{Atretic follicles}

The atretic follicles formed $19.7 \%$ of the population of antral follicles. The percentage of atretic follicles of Class 1 was very small going from $0.0 \%$ at Day 25 to $0.3 \%$ at Day 35 . A post-partum interval effect was detected in the percentage atretic follicles of Class 2 in that atresia increased from $1.9 \%$ on Day 15 to $7.2 \%$ on Day $35(P<0.06)$. The ovary bearing the CL contained significantly $(P<0.03)$ fewer atretic follicles of Classes 3 and 4 . The rate of atresia amongst antral follicles of Classes 5 and 6 was the same for the different days post partum and ovary type.

The degree of degeneration of the granulosa cells of the atretic follicles was evaluated according to the follow $₹$ g, three categories: (1) early atresia (5-25 pycnotic bodies), (2) intermediate atresia (a few rows of granulosa cells still intact against the basement membrane) and (3) late atresia (no gran- 


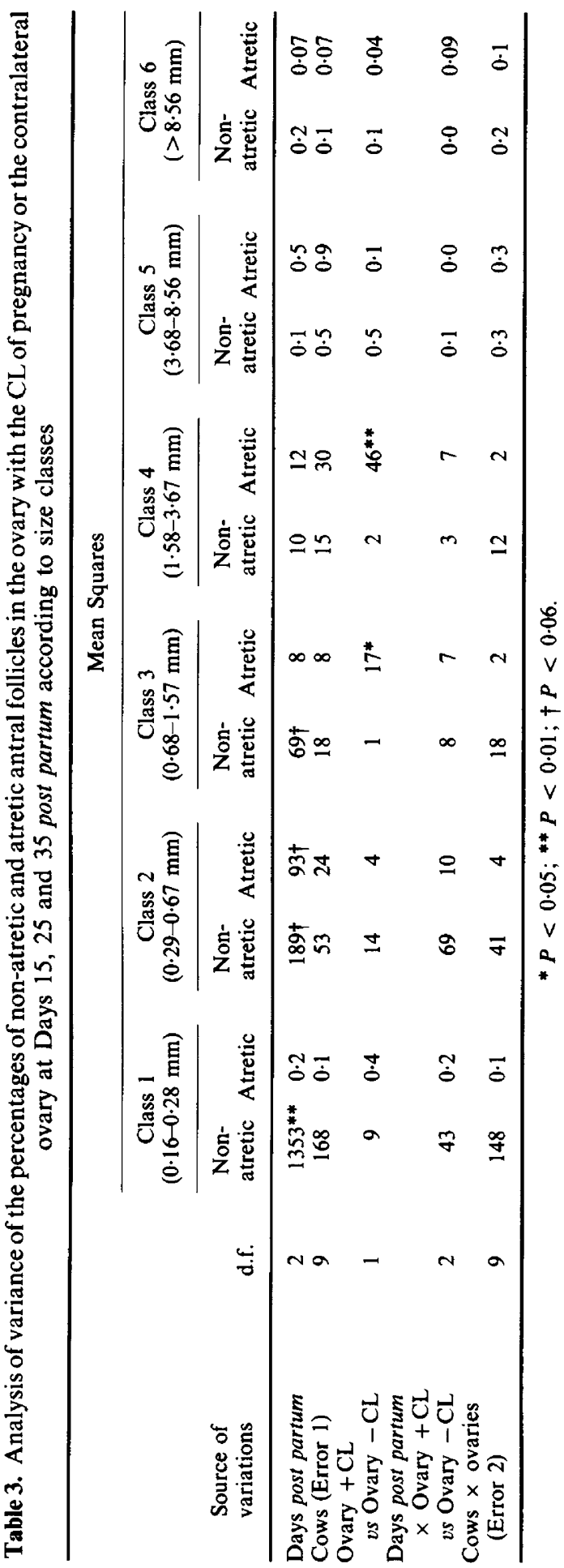


Table 4. Percentage of atretic follicles according to the degenerative index and the size class, status of ovary or status of ovary by size class regrouped

\begin{tabular}{|c|c|c|c|c|}
\hline & & \multicolumn{3}{|c|}{ Degenerative index } \\
\hline & & Early & Intermediate & Late \\
\hline $\begin{array}{l}\text { (a) Size c } \\
2 \\
3 \\
4 \\
5\end{array}$ & & $\begin{array}{r}6 \cdot 0 \\
4 \cdot 3 \\
24 \cdot 2 \\
27 \cdot 8\end{array}$ & $\begin{array}{r}10 \cdot 7 \\
7 \cdot 0 \\
37.9 \\
38.9\end{array}$ & $\begin{array}{l}83 \cdot 3 \\
88 \cdot 6 \\
37 \cdot 9 \\
33 \cdot 3\end{array}$ \\
\hline $\begin{array}{l}\text { (b) Status } \\
-C L \\
+C L\end{array}$ & & $\begin{array}{l}16 \cdot 7 \\
10 \cdot 3\end{array}$ & $\begin{array}{l}21 \cdot 0 \\
23 \cdot 1\end{array}$ & $\begin{array}{l}62 \cdot 3 \\
66 \cdot 6\end{array}$ \\
\hline $\begin{array}{l}\text { (c) Status } \\
-\mathrm{CL}\end{array}$ & $\begin{array}{c}\text { by } \operatorname{siz} \\
2-3 \\
4-5\end{array}$ & $\begin{array}{l}23 \cdot 1 \\
76 \cdot 9\end{array}$ & $\begin{array}{l}17 \cdot 3 \\
82 \cdot 7\end{array}$ & $\begin{array}{l}72 \cdot 4 \\
27 \cdot 6\end{array}$ \\
\hline$+\mathrm{CL}$ & $\begin{array}{l}2-3 \\
4-5\end{array}$ & $\begin{array}{l}10 \cdot 5 \\
89 \cdot 5\end{array}$ & $\begin{array}{l}23 \cdot 5 \\
76 \cdot 5\end{array}$ & $\begin{array}{l}73 \cdot 5 \\
26 \cdot 5\end{array}$ \\
\hline
\end{tabular}

For (a), $\chi^{2}(6)=219.63$.

For $(b), \chi^{2}(2)=7.08$.

For (c), $\chi^{2}(2)=7.78$.

ulosa cell against the basement membrane). More than $80 \%$ of the atretic follicles of Classes 2 and 3 were considered to be in late atresia (Table 4 ) while those of Classes 4 and 5 were evenly distributed amongst the 3 categories of atresia. Days post partum did not affect the degree of atresia. An effect of the CL of the previous pregnancy was detected amongst follicles of Classes 2-5 and Classes 2 and 3 were responsible for this effect. Early atresia was more frequent in the ovary without the CL reaching a similar percentage at the intermediate level. There were fewer early atretic follicles in the ovary with the CL for Classes 2 and 3, denoting a slow down in normal follicular activity.

\section{Cumulative effects of corpora lutea}

Three cows at Day 35 and one at Day 25 had ovulated by the time the ovaries were collected. Two of them had ovulated ipsilaterally to the side of the previous pregnancy. Thus, a $2 \times 2$ factorial arrangement was possible with the following factors: (1) ovary with or without CL and (2) type of

Table 5. The effect of the side of pregnancy on the distribution of ovarian follicles of cows which resumed ovarian activity

\begin{tabular}{lccc}
\hline & & \multicolumn{2}{c}{$\begin{array}{c}\text { Status of the ovary during } \\
\text { pregnancy }\end{array}$} \\
\cline { 3 - 4 } \multicolumn{1}{c}{$\begin{array}{c}\text { Status of the } \\
\text { ovary after } \\
\text { variable }\end{array}$} & $+\mathrm{CL}$ & $+\mathrm{CL}$ & $-\mathrm{CL}$ \\
\hline Total non-atretic follicles $(\%)$ & $-\mathrm{CL}$ & $83 \cdot 0^{\mathrm{a}}$ & $73 \cdot 9^{\mathrm{b}}$ \\
Non-atretic follicles in Class $3(\%)$ & $+\mathrm{CL}$ & $79 \cdot 1^{\mathrm{a}}$ & $74 \cdot 1^{\mathrm{b}}$ \\
& $-\mathrm{CL}$ & $21 \cdot 6^{\mathrm{y}}$ & $18 \cdot 2^{\mathrm{x}}$ \\
No. of non-atretic follicles in Class 6 & $+\mathrm{CL}$ & $15 \cdot 3^{\mathrm{x}}$ & $14 \cdot 8^{\mathrm{x}}$ \\
& $-\mathrm{CL}$ & $0 \cdot 0^{\mathrm{k}}$ & $0 \cdot 5^{\mathrm{k}}$ \\
& & $1 \cdot 5^{\mathrm{k}}$ & $1 \cdot 0^{1}$ \\
\hline
\end{tabular}


CL. In the 4 cows in which ovarian activity had resumed, $81 \%$ of the follicles in the ovary with the CL of pregnancy were non-atretic compared with $74 \%$ in the ovary without the pregnancy CL $(P<$ 0.01 ; Table 5). The new CL did not change significantly the distribution of the total number of nonatretic follicles. When the new ovulation was ipsilateral to that of the previous pregnancy, the percentage non-atretic follicles of Class 3 was significantly higher $(P<0.01)$ than when the new CL was contralateral to the $\mathrm{CL}$ of the last pregnancy or when no CL was present in the ovary.

The post-calving status of the ovary significantly influenced the number of non-atretic follicles of Class 6 (Table 5). The ovaries bearing the new CL contained on average only 0.25 follicles that were $>8.36 \mathrm{~mm}$ in diameter compared with 1.25 in the ovaries that had no new $\mathrm{CL}$, irrespective of the status of the ovary in relation to the $\mathrm{CL}$ of pregnancy.

\section{Discussion}

The percentage of non-atretic follicles present in an ovary was observed to decrease as the postpartum interval lengthened. This event was associated with the depletion of follicles of Class 1 which were nearly absent by Day 35 and therefore indicates that the early post-partum period is not conducive to the build-up of small follicles of Class 1. As during the anoestrous period in sheep (Cahill \& Mauléon, 1980; Dufour \& Guilbault, 1984), pregnancy in the cow would appear to be necessary for the restocking of antral follicles which then become available for the next reproductive cycle. During the post-partum period, follicles of large sizes increased in number concurrently with the rate of atresia.

The CL of the pregnancy just terminated inhibited the increase in the percentage of atretic follicles as the post-partum interval lengthened. The CL could therefore limit the growth rate of the developing follicles and thereby reduce their ultimate atresia. The evidence that the CL of the pregnancy was affecting follicular development and ultimately atresia is supported by the fact that most of the atretic follicles are in a late degenerative stage. Lewis, Thatcher, Bliss, Drost \& Collier (1984), using ovarian volume, diameter of the largest follicle and percentage of ovaries with a CL, also observed a restraining effect of the gravid uterine horn of the previous pregnancy. This inhibitory action on follicular development had disappeared, however, in cows that resumed ovarian activity after calving. The percentage of non-atretic follicles of Class 3 was greater in the ovary that had a new CL ipsilateral to that of the previous pregnancy. Therefore, the carry-over effect of the CL of pregnancy was removed by the presence of a new CL. Maurasse, Matton \& Dufour (1985) also observed that the ovary with the CL in cyclic heifers had more follicles of Class 3 than did the ovary without the CL but only within the animals on a high plane of nutrition.

The inhibitory carry-over effect of the gravid horn on fertility and/or on the side of ovulation (Saiduddin et al., 1967; Marion \& Gier, 1968) is also detected from the distribution of follicles examined microscopically. If one assumes that follicles of small size are the precursors of larger ones, then the inhibitory effect of the gravid horn will affect the follicles of smaller size first, leaving more of the large follicles available for the next ovulation. Lewis et al. (1984) observed such an effect during the first 50 days post partum.

Follicles in Classes 2, 3 and 4 appear to be the most sensitive. In the present study, days post partum and/or the CL status of the ovary had a significant effect on their distribution. Similarly, in a previous study with cyclic heifers, Maurasse et al. (1985) reported a significant effect on the number of follicles within these size classes due to days of the oestrous cycle, energy level of the ration and/or the CL status of the ovary. Any treatment likely to increase the number of follicles within the largest size class and/or the ovulation rate could there be presumed to do so by stimulating follicles of Classes 2, 3 and 4, since follicles $>3.68 \mathrm{~mm}$ in diameter (Classes 5 and 6) remained statistically unchanged throughout the post-partum period and in cyclic heifers (Maurasse et al., 1985). The evidence that follicles $>0.68$ and $<3.68 \mathrm{~mm}$ (Classes 3 and 4 ) double their size in 2.3 to 2.9 days (unpublished) leads one to speculate that these follicles (Monniaux, Chupin \& Saumande, 1983) 
would then be the ones to ovulate after gonadotrophin treatment. Similarly, the prevention of atresia in small-sized antral follicles might account for the increased ovulation rate observed in superovulated cows.

We thank $\mathrm{Mr}$ A. Bouchard for the histology and Mr A. Lemaire for care of the animals. Contribution No. 154.

\section{References}

Cahill, L.-P. \& Mauléon, P. (1980) Influences of season, cycle and breed on follicular growth rates in sheep. $J$. Reprod. Fert. 58, 321-328.

Dufour, J.J. \& Guilbault, L.A. (1984) Ovarian follicular population changes with the advance of the breeding season in intact and unilaterally ovariectomized ewes. J. Reprod. Fert. 70, 363-368.

Lewis, G.-S., Thatcher, W.W., Bliss, E.L., Drost, M. \& Collier, R.J. (1984) Effects of heat stress during pregnancy on post partum reproductive changes in Holstein cows. J. Anim. Sci. 58, 174-186.

Mariana, J.C. \& N'Guyen, H.N. (1973) Folliculogenese chez la vache. Annls Biol. anim. Biochim. Biophys. 13, 211-221.

Marion, G.B. \& Gier, H.T. (1968) Factors affecting bovine ovarian activity after parturition. J. Anim. Sci. 27, 1621-1626.

Maurasse, C., Matton, P. \& Dufour, J.J. (1985) Ovarian follicular populations at two stages of an estrous cycle in heifers fed a high or a low plane of nutrition. $J$. Anim. Sci. (in press).
Monniaux, D., Chupin, D. \& Saumande, J. (1983) Superovulatory responses of cattle. Theriogenology 19, 5581.

Nalbandov, A. \& Casida, L.E. (1940) Gonadotropic action of pituitaries from pregnant cows. Endocrino$\log y 27,559-566$.

Rexroad, C.E. \& Casida, L.E. (1975) Ovarian follicular development in cows, sows and ewes in different stages of pregnancy as affected by number of corpora lutea in the same ovary. J. Anim. Sci. 41, 1090-1097.

Saiduddin, S., Riesen, J.W., Tyler, W.J. \& Casida, L.E. (1967) Some carry-over effects of pregnancy on postpartum ovarian function in the cow. J. Dairy Sci. 50, 1846-1847.

Steel, R.G.D. \& Torrie, J.H. (1960) Principles and Procedures of Statistics. McGraw-Hill, New York.

Received 18 May 1984 